\title{
Irrigated wheat subjected to inoculation with Azospirillum brasilense and nitrogen doses as top-dressing
}

\author{
Cleiton J. Alves ${ }^{1}$, Orivaldo Arf ${ }^{2}$, Ane F. Ramos ${ }^{3}$, Fernando S. Galindo ${ }^{3}$, \\ Lais M. Nogueira ${ }^{3} \&$ Ricardo A. F. Rodrigues ${ }^{4}$ \\ ${ }^{1}$ Universidade Estadual Paulista "Júlio de Mesquita Filho"/Faculdade de Ciências Agronômicas. Botucatu, SP. E-mail: cleiton.agr.feis@gmail.com (Corresponding \\ author) \\ ${ }^{2}$ Universidade Estadual Paulista “Júlio de Mesquita Filho"/Faculdade de Engenharia/Departamento de Fitotecnia, Tecnologia de Alimentos e Sócio Economia. \\ Ilha Solteira, SP. E-mail: arf@agr.feis.unesp.br \\ ${ }^{3}$ Universidade Estadual Paulista "Júlio de Mesquita Filho"/Faculdade de Engenharia. Ilha Solteira, SP. E-mail: aneframos@gmail.com; fs.galindo@bol.com.br; \\ lais-meneghini@hotmail.com \\ ${ }^{4}$ Universidade Estadual Paulista “Júlio de Mesquita Filho"/Faculdade de Engenharia/Departamento de Fitossanidade, Engenharia Rural e Solos. Ilha Solteira, \\ SP. E-mail: ricardo@agr.feis.unesp.br
}

\section{Key words:}

Triticum aestivum L. nitrogen fertilization plant growth-promoting bacteria Cerrado

\begin{abstract}
A B S T R A C T
The use of Azospirillum brasilense in the wheat crop still presents contradictory results; thus, it is necessary to identify ideal conditions to obtain satisfactory results. The objective of this study was to investigate the interaction between Azospirillum brasilense and nitrogen doses in a wheat cultivar, conducted with irrigation in the Cerrado region of Mato Grosso do Sul. The experimental design was randomized blocks with a $4 \times 2$ factorial scheme, four nitrogen doses $\left(0,40,80\right.$ and $\left.120 \mathrm{~kg} \mathrm{ha}^{-1}\right)$ applied as top-dressing, associated or not with inoculation of wheat seeds with Azospirillum brasilense. The results show that there was no interaction between $\mathrm{N}$ and inoculation. The isolated effect of Azospirillum brasilense promotes an increase in plant height and number of grains per spike. Nitrogen doses promotes significant increases in leaf $\mathrm{N}$ content, plant height, number of grains per spike, number of spikes per square meter and grain yield. The conditions under which the experiment was conducted favored the development of the crop, not interfering with grain yield due the inoculation with Azospirillum brasilense.
\end{abstract}

\section{Palavras-chave: \\ Triticum aestivum $\mathrm{L}$. adubação nitrogenada bactérias promotoras do crescimento de plantas Cerrado}

\section{Trigo irrigado submetido à inoculação com Azospirillum brasilense e doses de nitrogênio em cobertura}

\section{R E S U M O}

A utilização de Azospirillum brasilense na cultura do trigo ainda apresenta resultados contraditórios, sendo necessário identificar as condições ideais para se obter resultados satisfatórios. Objetivou-se, com o trabalho, investigar a interação entre Azospirillum brasilense e doses de nitrogênio em trigo na região de Cerrado Sul-Mato-Grossense. Adotou-se um delineamento em blocos casualizados com esquema fatorial $4 \times 2$, sendo quatro doses de nitrogênio $\left(0,40,80\right.$ e $\left.120 \mathrm{~kg} \mathrm{ha}^{-1}\right)$ aplicadas em cobertura, associadas à inoculação ou não de sementes de trigo com Azospirillum brasilense. Os resultados mostram que não houve interação entre as doses de $\mathrm{N}$ e a inoculação. O efeito isolado do Azospirillum brasilense proporcionou aumento na altura de plantas e número de grãos por espiga. As doses de nitrogênio promoveram incrementos significativos no teor de $\mathrm{N}$ foliar, altura de plantas, número de grãos por espiga, número de espigas por metro quadrado e produtividade de grãos. As condições em que o experimento foi conduzido favoreceram o desenvolvimento da cultura, não interferindo na produtividade de grãos em função da inoculação com Azospirillum brasilense.

Ref. 167-2016 - Received 6 Oct, 2016 • Accepted 17 Feb, 2017 • Published 29 Jun, 2017 


\section{INTRODUCTION}

Wheat is one of the most produced cereals in the world; its flour is widely used in the manufacture of breads, masses and cookies, adapting to various ecosystems, which allows its production at different altitudes. In Brazil, it is the winter crop with greatest importance, cultivated mainly in the South, Southeast and Midwest regions. The national area occupied by wheat is estimated to be 2.48 million hectares with a mean yield of 2,260 kg ha' (CONAB, 2016).

The advancement of research involving microbiology in agriculture has intensified the use of plant growth-promoting bacteria (PGPB), capable of performing biological fixation of the atmospheric nitrogen $(\mathrm{N})$, reducing the necessity of $\mathrm{N}$ fertilization in leguminous crops, decreasing costs for farmers. Azospirillum brasilense is a PGPB capable of colonizing the root system of plants, increasing the root system, producing phytohormones such as auxins, gibberellins and cytokinins (Richardson et al., 2009, Yang et al., 2009), improving the absorption of nutrients and performing biological $\mathrm{N}$ fixation (Hungria, 2011).

Studies report that the utilization of $A$. brasilense in the wheat crop promotes plant growth, greater $\mathrm{N}$ accumulation in the leaves (Sala et al., 2005), increase of yield without additional $\mathrm{N}$ (Sala et al., 2007), more efficient $\mathrm{N}$ translocation to the grains, heavier grains and better redistribution of the $\mathrm{N}$ present in the biomass to the grains (Didonet et al., 2000). In contrast, studies demonstrate that the inoculation does not contribute to the increase in production components, yield and $\mathrm{N}$ supply for the wheat crop (Rodrigues et al., 2014, Nunes et al., 2015).

One of the factors that justify the inconsistency of results involving A. brasilense inoculation in wheat is the interference of the cultivation site (Sala et al., 2007), because there are variations of rainfall, temperature and soil fertility. Thus, there is a necessity of studies that elucidate the effect of $A$. brasilense under field conditions with adequate water and nutritional availability.

This study aimed to investigate if Azospirillum brasilense inoculation and $\mathrm{N}$ doses promote increments in the production components, $\mathrm{N}$ absorption and grain yield in the wheat crop, conducted in irrigated environment in the Cerrado of Mato Grosso do Sul.

\section{Material and Methods}

The experiment was carried out in 2014, in an experimental area of the Engineering Faculty - UNESP, Campus of Ilha Solteira, located in the municipality of Selvíria - MS, situated at approximately $51^{\circ} 22^{\prime} \mathrm{W}$ and $20^{\circ} 22^{\prime} \mathrm{S}$, with altitude of $335 \mathrm{~m}$.

The soil of the experimental area was classified as dystroferric Red Latosol, clayey texture, according to the classification of EMBRAPA (2013). The annual climatic means are rainfall of $1370 \mathrm{~mm}$, temperature of $23.5^{\circ} \mathrm{C}$ and relative air humidity between 60 and $80 \%$. The climate of the region is Aw, according to Köppen's classification, defined as humid tropical, with rainy season in the summer and dry season in the winter. The climatic data relative to the experimental period are presented in Figure 1.

The experimental design was randomized blocks, arranged in a $4 \times 2$ factorial scheme, with 4 replicates. The treatments consisted of doses of $\mathrm{N}$ in the form of urea (0, 40, 80 and 120 $\mathrm{kg} \mathrm{ha}^{-1}$ of $\mathrm{N}$ ), applied as top-dressing, combined with and without seed inoculation with Azospirillum brasilense, totaling 8 treatments. The plots consisted of six 5 -m-long rows spaced by $0.17 \mathrm{~m}$, and the area used for evaluation and harvest was considered as the 4 central rows.

Before the experiment was installed, soil samples were collected in the experimental area and chemically analyzed according to the method proposed by Raij et al. (1996). The results were $11 \mathrm{mg} \mathrm{dm}^{-3}$ of $\mathrm{P}, 19 \mathrm{~g} \mathrm{dm}^{-3}$ of $\mathrm{OM}, \mathrm{pH}$ in $\mathrm{CaCl}_{2}$ 5.0, K, Ca, Mg, H+Al, Al, SB, CEC = 0.8; 14; 14; 31; 1;28.8; $59.8 \mathrm{mmol}_{\mathrm{c}} \mathrm{dm}^{-3}$, respectively and $\mathrm{V}=48 \%$.

Conventional tillage was performed in the area, through plowings and harrowings. The limestone dose necessary to increase base saturation to $60 \%$ was applied in the area and incorporated during the tillage operations in the layer of 0-20 $\mathrm{cm}$. Sowing occurred on May 12, 2014, aiming at a density of 400 plants $\mathrm{m}^{-2}$. Basal fertilization consisted in $200 \mathrm{~kg} \mathrm{ha}^{-1}$ of the 08-28-16 formulation, based on soil chemical analysis for an expected yield of 2-3 $\mathrm{t} \mathrm{ha}^{-1}$ (Cantarella et al., 1997).

The experiment used the cultivar CD 116, recommended for cultivation in Mato Grosso do Sul, with early cycle, low height, intermediate position of the leaves and moderately resistant to lodging.

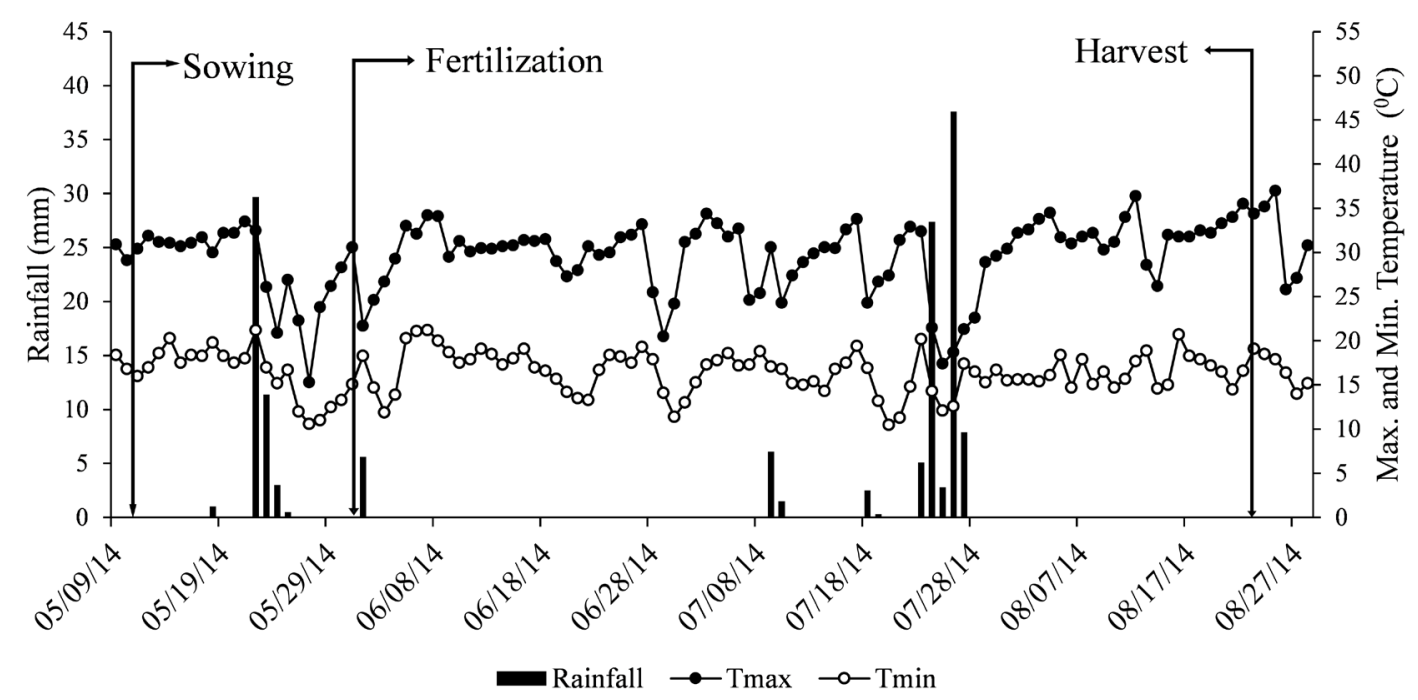

Figure 1. Data of rainfall, maximum and minimum temperature along the experimental period 
A fixed sprinkler irrigation system was installed in the experimental area and water management was made when necessary, according to Technical Information for Wheat and Triticale (Montecelli et al., 2014), which takes into consideration the evapotranspiration and development stage of the crop.

Azospirillum brasilense inoculation was performed in the shade, with the strains $\mathrm{Ab}-\mathrm{V}_{5}$ and $\mathrm{Ab}-\mathrm{V}_{6}$. The utilized inoculant had the concentration of $2 \times 10^{8}$ viable cells per gram of the commercial product, using the dose of $100 \mathrm{~g}$ of inoculant for $25 \mathrm{~kg}$ of seeds. The doses of urea were applied 20 days after emergence (DAE), in the morning, followed by irrigation, to avoid losses through volatilization. Harvest was performed at 101 DAE.

The following variables were evaluated: leaf $\mathrm{N}$ content, in the flag leaf, collected at the beginning of the flowering stage (Cantarella et al., 1997); plant height at maturation, defined as the distance $(\mathrm{m})$ from the soil to the tip of the spikes, disregarding the awns; number of spikes per square meter at harvest; total number of grains per spike at harvest, evaluated in 20 wheat spikes per experimental unit; hectoliter weight, corresponding to the grain mass occupying a volume of $100 \mathrm{~L}$, determined on scale of $1 / 4$, with moisture content in the grains corrected to $13 \%$ w.b. (wet basis); 1000-grain weight, determined on precision scale $(0.01 \mathrm{~g})$ with moisture content in the grains corrected to $13 \%$ w.b.; grain yield, determined by the collection of the plants contained in the four central rows of each plot. After mechanical threshing, the grains were weighed and the values were transformed to kilograms per hectare, with $13 \%$ w.b.

The obtained data were subjected to analysis of variance (F test) and the means were compared by Tukey test at 0.05 probability level, using the statistical program Sisvar 5.3 (Ferreira, 2010).

\section{Results AND Discussion}

There was no interaction between the factors Azospirillum brasilense inoculation and $\mathrm{N}$ doses, in any of the evaluations presented in Table 1.

Table 1. F test probability values and means of leaf nitrogen content, plant height, spikes $\mathrm{m}^{-2}$ and grains per spike, as a function of Azospirillum inoculation of seeds and nitrogen doses applied as top-dressing in the wheat crop

\begin{tabular}{lcccc}
\multicolumn{1}{c}{ Treatments } & $\begin{array}{c}\text { Leaf } \mathbf{N} \\
\mathbf{g ~ k g}^{-1}\end{array}$ & $\begin{array}{c}\text { Plant height } \\
\mathbf{M}\end{array}$ & Spikes $\mathbf{~ m}^{-2}$ & Grains spike $^{-1}$ \\
Inoculation (I) & & & & \\
With & 45.81 & $0.69 \mathrm{a}$ & 396 & $38.2 \mathrm{a}$ \\
Without & 45.79 & $0.67 \mathrm{~b}$ & 393 & $34.1 \mathrm{~b}$ \\
\hline $\mathrm{N}$ doses $\left(\mathrm{kg} \mathrm{ha}^{-1}\right)(\mathrm{N})$ & & & & \\
0 & 41.10 & 0.64 & 313 & 29.1 \\
40 & 45.28 & 0.67 & 381 & 36.9 \\
80 & 48.01 & 0.70 & 447 & 38.2 \\
120 & 48.81 & 0.71 & 438 & 40.3 \\
\hline F test & & & & \\
I & 0.9844 & 0.0297 & 0.7083 & 0.0058 \\
$\mathrm{~N}$ & 0.0001 & 0.0002 & $<0.0001$ & $<0.0001$ \\
Ix N & 0.9290 & 0.5716 & 0.0785 & 0.0812 \\
\hline
\end{tabular}

Means followed by different letters in the columns are statistically different by Tukey test at 0.05 probability level
The isolated effect of wheat seed inoculation with $A$. brasilense promoted greater plant height and higher number of grains per spike, while the leaf $\mathrm{N}$ content and number of spikes per square meter were not influenced (Table 1).

The results for leaf $\mathrm{N}$ content corroborate those of Nunes et al. (2015), who worked with A. brasilense inoculation and $\mathrm{N}$ doses in irrigated wheat in environments with high and low $\mathrm{N}$ availability, and observed that the $\mathrm{N}$ content in wheat shoots was not influenced by the inoculation of A. brasilense in both environments.

Plant height is a characteristic that can be influenced by factors such as $\mathrm{N}$ availability and action of growth hormones. Since inoculation favored plant height and there was no increment in leaf $\mathrm{N}$ content, it is believed that this effect was due to the hormonal contribution of $A$. brasilense and not to the biological fixation of atmospheric N. Such biological characteristic of $A$. brasilense is also reported by Dobbelaere et al. (2002).

Regarding the number of grains per spike, Lemos et al. (2013), studying five wheat cultivars grown in controlled environment, using inoculation associated with $\mathrm{N}$ doses, observed that there was no influence of inoculation on this component, regardless of the cultivar, which differs from the results of the present study.

Lemos et al. (2013) also found different results for leaf $\mathrm{N}$ content, in which the cultivars CD 108 and CD 150 positively responded to the inoculation, compared with the control. Rodrigues et al. (2014), using a combination of Azospirillum brasilense and humic acids with different $\mathrm{N}$ doses in wheat cultivated in greenhouse, reported that such combination does not cause significant effect on the production components.

Nunes et al. (2015) report that the number of grains per spike in wheat plants was not influenced by $A$. brasilense inoculation in soil with low $\mathrm{N}$ availability and that, under conditions of high $\mathrm{N}$ availability, the inoculation may damage this production component, different from the results obtained in the present study.

For Lemos et al. (2013), the response to A. brasilense inoculation in the wheat crop occurs satisfactorily when inoculation is performed along with $\mathrm{N}$ fertilization, elucidating the question that $A$. brasilense helps crop development with reflex in the quality and yield, but does not substitute $\mathrm{N}$ fertilization, eventually decreasing the $\mathrm{N}$ dose to be applied. Such response differs from the results obtained in the present study, which did not indicate any effect of the interaction between $\mathrm{N}$ doses and A. brasilense inoculation on the production parameters of the wheat crop. These results indicate that $A$. brasilense possibly promotes improvements in plant development and production, but does not reduce the necessity of $\mathrm{N}$ to be applied.

For the applied $\mathrm{N}$ doses, the results of the variables leaf $\mathrm{N}$ content (Figure 2A) and plant height (Figure 2B) showed a positive linear fit, with gains of 18.7 and $10.9 \%$, respectively, with the highest dose in relation to the $\mathrm{N}$ dose of $0 \mathrm{~kg} \mathrm{ha}^{-1}$. The variables spikes per square meter (Figure $2 \mathrm{C}$ ) and grains per spike (Figure 2D) fitted to the quadratic equation, with highest results at the $\mathrm{N}$ doses of 106 and $107 \mathrm{~kg} \mathrm{ha}^{-1}$, respectively. 
A.

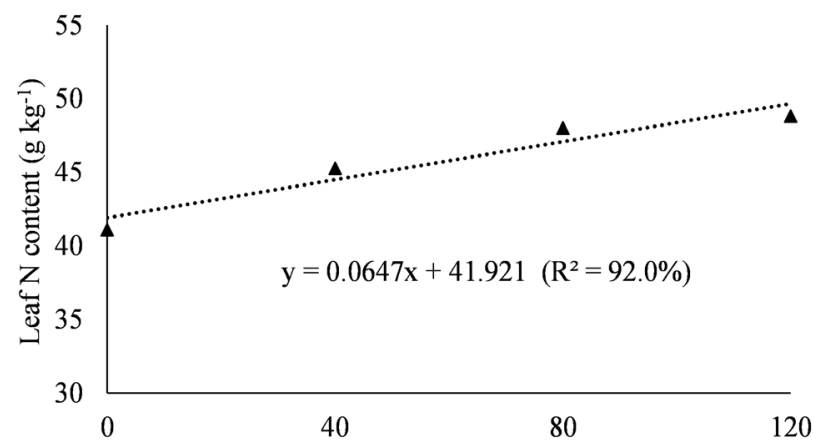

C.

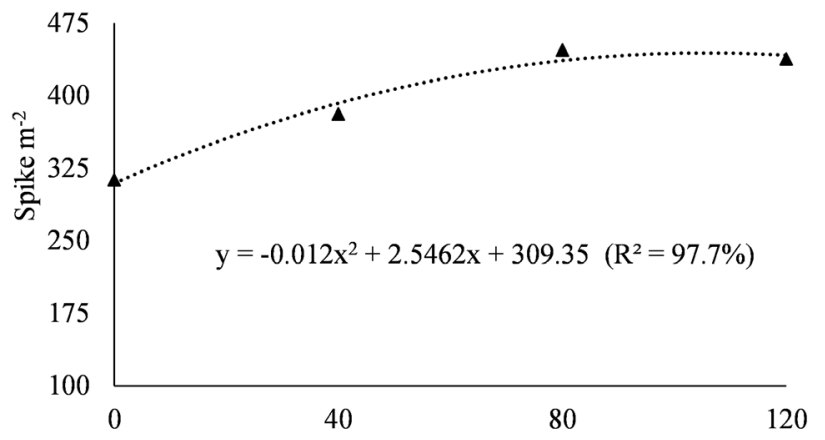

B.

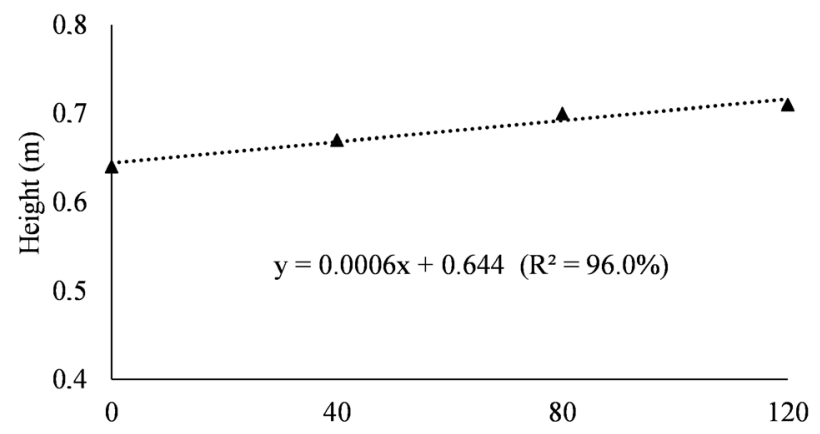

D.

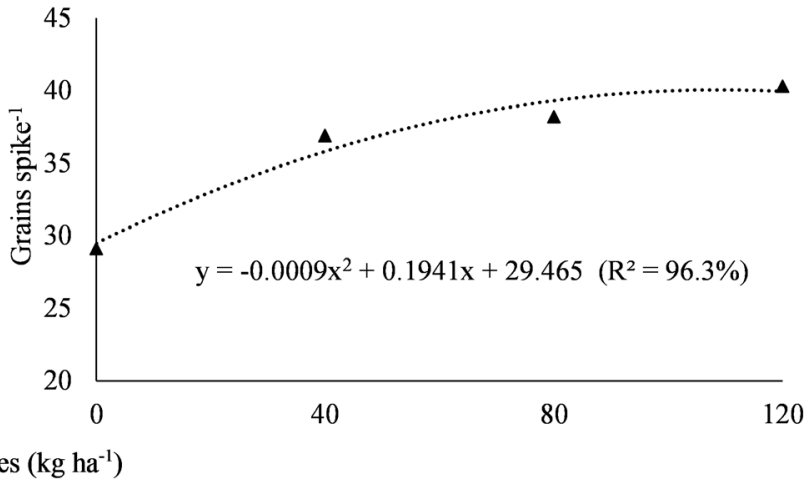

Figure 2. Leaf $\mathrm{N}$ content (A), plant height (B), number of spikes $\mathrm{m}^{-2}(\mathrm{C})$ and grains spike ${ }^{-1}(\mathrm{D})$ as a function of the $\mathrm{N}$ doses applied as top-dressing

The observed leaf $\mathrm{N}$ contents are above the value recommended by Cantarella et al. (1997), including at the $\mathrm{N}$ dose of $0 \mathrm{~kg} \mathrm{ha}^{-1}$, possibly due to the reserve present in the soil and organic matter decomposition and mineralization. The excessive content of leaf $\mathrm{N}$ in the wheat crop was also reported by Teixeira Filho et al. (2008), studying $\mathrm{N}$ doses as top-dressing $\left(0,30,60,90,120\right.$ and $\left.150 \mathrm{~kg} \mathrm{ha}^{-1}\right)$ and different wheat cultivars with irrigation in the Cerrado region and Teixeira Filho et al. (2010) studying sources, doses $\left(0,50,100,150\right.$ and $\left.200 \mathrm{~kg} \mathrm{ha}^{-1}\right)$ and period of $\mathrm{N}$ application.

There was a linear increase in the variable plant height as a function of the $\mathrm{N}$ doses, because the increment of $\mathrm{N}$ stimulates stem elongation in cereals. According to Espindula et al. (2010), the greatest plant length comes accompanied by higher susceptibility to lodging. The authors also report that the genetic characteristics can promote higher resistance to lodging, justifying the absence of lodging for the cultivar CD 116 in the present study.

$\mathrm{N}$ availability favored better nutritional condition at the moment of flower differentiation, which resulted in the increase in the number of grains per spike, due to the applied $\mathrm{N}$ doses. Similar results were obtained by Espindula et al. (2010), studying doses $\left(0,40,60,80,100\right.$ and $120 \mathrm{~kg} \mathrm{ha}^{-1}$ of $\left.\mathrm{N}\right)$ and forms of application of $\mathrm{N}$ in the wheat crop. On the other hand, Teixeira Filho et al. $(2007,2008,2010)$ did not find difference in the number of grains per spike as a function of the $\mathrm{N}$ doses in the wheat crop.

The number of spikes per square meter is a variable that depends on the number of tillers that the plant produces, maintains and develops until the end of the cycle. According to Ramos (1973), the number of tillers is directly influenced by the
$\mathrm{N}$ availability during the tillering stage, but the production of tillers is limited because of the compensatory effect (Espindula et al., 2010; Pietro-Souza et al., 2013), justifying the maximum production of spikes per square meter when the $\mathrm{N}$ dose of 106 $\mathrm{kg} \mathrm{ha}^{-1}$ was applied.

There was no interaction between the factors Azospirillum brasilense inoculation and $\mathrm{N}$ doses, in any of the evaluations presented in Table 2. For the individual effect of inoculation, there was difference only for the variable hectoliter weight, in which the treatment without $A$. brasilense reached the highest means.

The 1000-grain weight and grain yield were not influenced by $A$. brasilense inoculation (Table 2). Rodrigues et al. (2014)

Table 2. F test probability values and means of 1000-grain weight, hectoliter weight and yield as a function of Azospirillum brasilense inoculation and $\mathrm{N}$ doses applied as top-dressing in the wheat crop

\begin{tabular}{|c|c|c|c|}
\hline Treatments & $\begin{array}{l}\text { 1000-grain weight } \\
\text { (g) }\end{array}$ & $\begin{array}{l}\text { Hectoliter weight } \\
(\mathrm{kg})\end{array}$ & $\begin{array}{c}\text { Grain yield } \\
\left(\mathrm{kg} \mathrm{ha}^{-1}\right)\end{array}$ \\
\hline \multicolumn{4}{|l|}{ Inoculation (I) } \\
\hline With & 34.6 & $82.8 b$ & 2.398 \\
\hline Without & 35.7 & $84.6 \mathrm{a}$ & 2.303 \\
\hline \multicolumn{4}{|c|}{$\bar{N}$ doses $\left(\mathrm{kg} \mathrm{ha}^{-1}\right)(\mathrm{N})$} \\
\hline 0 & 35.8 & 83.7 & 1.617 \\
\hline 40 & 35.0 & 83.9 & 2.183 \\
\hline 80 & 34.7 & 84.0 & 2.636 \\
\hline 120 & 35.1 & 83.2 & 2.964 \\
\hline \multicolumn{4}{|l|}{ F test } \\
\hline | & 0.1405 & 0.0165 & 0.4774 \\
\hline $\mathrm{N}$ & 0.7525 & 0.8537 & $<0.0001$ \\
\hline $\mathrm{I} \times \mathrm{N}$ & 0.8121 & 0.7830 & 0.7940 \\
\hline
\end{tabular}

Means followed by different letters in the columns are statistically different by Tukey test at 0.05 probability level 
and Nunes et al. (2015) also report that the inoculation of wheat with $A$. brasilense does not promote increments in yield. Differently, Zorita \& Caniggia (2009), after inoculating A. brasilense in wheat seeds, obtained expressive increments in grain yield.

The absence of increments in the yield promoted by inoculation can be explained by the interference of the cultivation site (Sala et al., 2007). According to Tiwari et al. (2011), PGPB induce physical and biochemical changes in the plants, conferring resistance under stress conditions. However, the supplementation of irrigation used along the experiment may have minimized possible effects of water stress, favoring the treatment without inoculation to the point of becoming equal to the inoculated treatment, not demonstrating difference in most analyzed variables.

Hectoliter weight is a variable that considers the mass of grains in a volume of $100 \mathrm{~L}$. Thus, this variable is related to grain filling. Although there was no influence of inoculation on the 1000-grain weight in the present study, grain filling may have been damaged by the compensatory effect, resulting in lower values for hectoliter weight in the treatment with $A$. brasilense. The reduction in the yield of the production components due to the compensatory effect is also reported by Espindula et al. (2010) and Pietro-Souza et al. (2013), studying the application of $\mathrm{N}$ doses in the wheat crop.

The isolated effect of $\mathrm{N}$ doses presented in Table 2 points to difference only in grain yield, whose results fitted to a linear equation, with highest $\mathrm{N}$ dose leading to $1,347 \mathrm{~kg} \mathrm{ha}^{-1}$ of grains more than the control (Figure 3). In the low-altitude Cerrado region, using $\mathrm{N}$ doses in the wheat crop, Teixeira Filho et al. (2010) and Melero et al. (2013) obtained maximum yields of 3,654 and 4,132 kg ha-1 with doses of 113 and $122 \mathrm{~kg} \mathrm{ha}^{-1}$ of $\mathrm{N}$, respectively. In the present study, the cultivar CD 116 responded linearly to the applied $\mathrm{N}$ doses, but did not achieve all the production potential, because the obtained yield is relatively low compared with studies conducted under similar conditions.

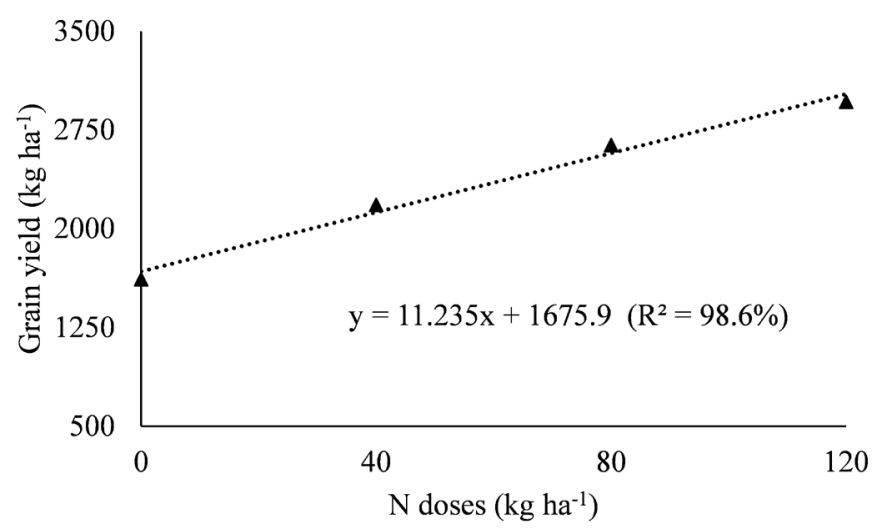

Figure 3. Grain yield of wheat as a function of $\mathrm{N}$ doses applied as top-dressing

\section{Conclusions}

1. The cultivar CD 116 responds to the increase in $\mathrm{N}$ doses, but there is no supply of $\mathrm{N}$ due to the inoculation with Azospirillum brasilense.
2. Under Cerrado conditions with supplementation of irrigation, there is no increment in wheat yield due to the inoculation with Azospirillum brasilense.

\section{Literature Cited}

Cantarella, H.; Raij, B. van; Camargo, C. E. O. Cereais. In: Raij, B. van; Cantarella, H.; Quaggio, J. A.; Furlani, A. M. C. Recomendações de calagem e adubação para o Estado de São Paulo. Campinas: IAC, 1997. 285p. Boletim Técnico, 100

CONAB - Companhia Nacional de Abastecimento. Acompanhamento da safra brasileira de grãos, v. 3 - Safra 2015/16, n. 8 - Oitavo levantamento, maio 2016, 178p. Disponível em: <http://www. conab.gov.br/OlalaCMS/uploads/arquivos/16_06_10_14_42_08_ boletim_graos_maio__2016_-_final.pdf $>$. Acessado em: 13 Mai. 2016.

Didonet, A. D.; Lima, O. dos S.; Candaten, A. A.; Rodrigues, O. Realocação de nitrogênio e de biomassa para os grãos, em trigo submetido a inoculação de Azospirillum. Pesquisa Agropecuária Brasileira, v.35, p.401-411, 2000. https://doi.org/10.1590/S0100204X2000000200019

Dobbelaere, S.; Croonenborghs, A.; Thys, A.; Ptacek, D.; Okon, T.; Vanderleyden, J. Effect of inoculation with wild type Azospirillum brasilense and $A$. irakense strains on development and nitrogen uptake of spring wheat and grain maize. Biology and Fertility of Soils, v.36, p.284-297, 2002. https://doi.org/10.1007/s00374002-0534-9

EMBRAPA - Empresa Brasileira de Pesquisa Agropecuária. Centro Nacional de Pesquisa de Solos. Sistema brasileiro de classificação de solos. 3.ed. Brasília: EMBRAPA, 2013, 353p.

Espindula, M. C.; Rocha, V. S.; Souza, M. A. de; Grossi, J. A. S.; Souza, L. T. de. Doses e formas de aplicação de nitrogênio no desenvolvimento e produção da cultura do trigo. Ciência e Agrotecnologia, v.34, p.1404-1411, 2010. https://doi. org/10.1590/S1413-70542010000600007

Ferreira, D. F. SISVAR - Programa estatístico. 5.3. Universidade Federal de Lavras, Lavras. Disponível em: $<$ http://www.dex.ufla. br/ danielff/programas/sisvar.html >. Acessado em 2010.

Hungria, M. Inoculação com Azospirillum brasilense: Inovação em rendimento a baixo custo. Londrina: Embrapa Soja, 2011. 37p. Documento, 325

Lemos, J. M.; Guimarães, V. F.; Vendruscolo. E. C. G.; Santos, M. F. dos; Offemann, L. C. Resposta de cultivares de trigo à inoculação de sementes com Azospirillum brasilense, e à adubação nitrogenada em cobertura. Científica, v.41, p.189-198, 2013.

Melero, M. M.; Gitti, D. de C.; Arf, O.; Rodrigues, R. A. F. Coberturas vegetais e doses de nitrogênio em trigo sob sistema plantio direto. Pesquisa Agropecuária Tropical, v.43, p.343-353, 2013. https://doi.org/10.1590/S1983-40632013000400001

Montecelli, A.; Dengler, R. U.; Lombardi, J. (org.). Informações técnicas para trigo e triticale - safra 2014. In: Reunião da Comissão Brasileira de Pesquisa de Trigo e Triticale, 7, 2014, Londrina. - Londrina: Fundação Meridional, 2014, 235p.

Nunes, P. H. M. P.; Aquino, L. A.; Santos, L. P. D. dos; Xavier, F. O.; Dezordi, L. R.; Assunção, N. S. Produtividade de trigo irrigado submetido à aplicação de nitrogênio e à inoculação com Azospirillum brasilense. Revista Brasileira de Ciência do Solo, v.39, p.174-182, 2015. https://doi. org/10.1590/01000683rbcs20150354 
Pietro-Souza, W.; Bonfim-Silva, E. M.; Schlichting, A. F.; Silva, M. de C. Desenvolvimento inicial de trigo sob doses de nitrogênio em latossolo vermelho de Cerrado. Revista Brasileira de Engenharia Agrícola e Ambiental, v.17, p.575-580, 2013. https://doi. org/10.1590/S1415-43662013000600001

Raij, B. van.; Cantarella, H.; Quaggio, J. A.; Furlani, A. M. C. Recomendações de adubação e calagem para o Estado de São Paulo. 2.ed. Campinas: IAC, 1996. 285p. Boletim Técnico, 100

Ramos, M. Efeitos do nitrogênio e fósforo sobre características agronômicas da variedade de trigo IAS 54 e suas relações com a produção. Pesquisa Agropecuária Brasileira, v.8, p.213-216, 1973.

Richardson, A. E.; Barea, J.-M.; McNeill, A. M.; Prigent-Combaret, C. Acquisition of phosphorus and nitrogen in the rhizosphere and plant growth promotion by microorganisms. Plant and Soil, v.321, p.305-339, 2009. https://doi.org/10.1007/s11104009-9895-2

Rodrigues, L. F. O. S.; Guimarães, V. F.; Silva, M. B. da; Pinto Junior, A. S.; Klein, J.; Costa, A. C. P. R. da. Características agronômicas do trigo em função de Azospirillum brasilense, ácidos húmicos e nitrogênio em casa de vegetação. Revista Brasileira de Engenharia Agrícola e Ambiental, v.18, p.31-37, 2014. https://doi.org/10.1590/ S1415-43662014000100005

Sala, V. M. R.; Cardoso, E. J. B. N.; Freitas, J. G. de; Silveira, A. P. D. da. Resposta de genótipos de trigo à inoculação de bactérias diazotróficas em condições de campo. Pesquisa Agropecuária Brasileira, v.42, p.833-842, 2007. https://doi.org/10.1590/S0100204X2007000600010
Sala, V. M. R.; Freitas, S. dos S.; Donzeli, V. P.; Freitas, J. G. de; Gallo, P. B.; Silveira, A. P. D. da. Ocorrência e efeito de bactérias diazotróficas em genótipos de trigo. Revista Brasileira de Ciência do Solo, v.29, p.345352, 2005. https://doi.org/10.1590/S0100-06832005000300004

Teixeira Filho, M. C. M.; Buzetti, S.; Alvarez, R. de C. F.; Freitas, J. G. de; Arf, O.; Sá, M. E. de. Resposta de cultivares de trigo irrigado por aspersão ao nitrogênio em cobertura na região do Cerrado. Acta Scientiarum. Agronomy, v.29, p.421-425, 2007.

Teixeira Filho, M. C. M.; Buzetti, S.; Alvarez, R. de C. F.; Freitas, J. G. de; Arf, O.; Sá, M. E. de. Desempenho agronômico de cultivares de trigo em resposta a população de plantas e a adubação nitrogenada. Científica, v.36, p.97-106, 2008.

Teixeira Filho, M. C. M.; Buzetti, S.; Andreotti, M.; Arf, O.; Benett, C. G. S. Doses, fontes e épocas de aplicação de nitrogênio em trigo irrigado em plantio direto. Pesquisa Agropecuária Brasileira, v.45, p.797-804, 2010. https://doi.org/10.1590/S0100-204X2010000800004

Tiwari, S.; Singh, P.; Tiwari, R.; Meena, K. K.; Yandigeri. M.; Singh, D. P.; Arora, D. K. Salt-tolerant rhizobacteria-mediated induced tolerance in wheat (Triticum aestivum) and chemical diversity in rhizosphere enhance plant growth. Biology and Fertility of Soils, v.47, p.907-916, 2011. https://doi.org/10.1007/s00374-011-0598-5

Yang, J.; Kloepper, J. W.; Ryu, C. M. Rhizosphere bacteria help plants tolerate abiotic stress. Trends in Plant Science, v.14, p.1-4, 2009. https://doi.org/10.1016/j.tplants.2008.10.004

Zorita, M. D.; Caniggia, M. V. F. Field performance of a liquid formulation of Azospirillum brasilense on dryland wheat productivity. European Journal of Soil Biology, v.45, p.3-11, 2009. https://doi.org/10.1016/j.ejsobi.2008.07.001 